printing any number of photographic copies in the usual way. Recently this process has been revived by Messrs. Luminophor, Ltd., 27 Queen Victoria Street, London, E.C.4, who supply phosphorescent screens to replace the ordinary light source of the original 'playertype'. One of the screens must first be excited by exposure to daylight or to magnesium light. It is then placed upon the bromide paper and drawing and allowed to remain for some minutes. Subsequent operations are similar to those already described for 'playertype'. However, while these phosphorescent screens are sometimes convenient, they are costly and really quite unnecossary.

\section{Beit Memorial Fellowships for Medical Research}

The following elections have been made by the Trustees of the Beit Memorial Fellowships for Medical Research, the subject and place of research being indicated after the name:-Senior Fellowship in Tropical Medicine ( $£ 1000$ a year, for one further year): Dr. E. Hindle, spirochætosis, with special reference to the causation of yellow fever. Fourth Year Fellowships (value $£ 500$ a year): Dr. C. L. Cope, excretion by the mammalian kidney of the glomerular dyestuffs and of the inert sugars believed to be excreted only by the glomeruli (Radcliffe Infirmary and Department of Biochemistry, Oxford); Margaret Honora Roscoe, to continue work on the vitamin B complex (Lister Institute of Preventive Medicine, London); Mr. K. A. C. Elliott, to complete work on peroxidases, and then to study tissue respiration from the point of view of carbon dioxide evolution (Sir William Dunn Institute of Biochemistry, Cambridge). Junior Fellowships ( $£ 400$ a year): Dr. H. P. Himsworth, activation of insulin by a possible kinase and effect of diets of varying composition on diabetic patients (University College Hospital Medical School, London); Mr. N. R. Lawrie, biochemical investigation of the nutritional requirements of Protozoa and the study of patients with abnormal metabolism of sulphur-containing compounds (Sir William Dunn Institute of Biochemistry, Cambridge, and Addenbrooke's Hospital, Cambridge) ; Dr. D. H. Williams, carbohydrate metabolism, particularly the storage of liver glycogen in experimental animals (Department of Physiology, University College, London); Mr. D. W. W. Henderson, antibacterial mechanisms in prophylaxis and therapy of tetanus; cultivation of the viruses of louping ill and fowlpox (Lister Institute of Preventive Medicine, London); Dr. R. G. R. West, neurological mechanism of tetany and the pharmacology of curare (Physiological Department, St. Bartholomew's Hospital Medical School); Dr. R. Gaddie, intermediate carbohydrate metabolism of isolated frog's heart; mode of action of insulin in the animal body (Departments of Medical Chemistry and Materia Medica, University of Edinburgh) ; Mr. F. G. Young, storage of carbohydrate by the liver in experimental animals (Departments of Physiology at University College, London, and at the University of Aberdeen); Dr. J. M. Robson, hormonic factors responsible for the maintenance of pregnancy and onset of parturition (Institute of Animal Genetics, Edinburgh).

$$
\text { No. 3272, VoL. 130] }
$$

\section{Beit Fellowships for Scientific Research}

BeIt Fellowships for Scientific Research of the annual value of $£ 240$ and tenable at the Imperial College of Science, South Kensington, have been awarded to Mr. R. M. Shackleton (University of Liverpool and Imperial College), for research on the geology of the area about Moel Hebog; Mr. E. G. Jones (University College, Nottingham, and the Einstein Institute, Astrophysics Observatory, Potsdam), for research on hyperfine structure of spectral lines; Mr. R. L. Rosenberg (Universities of Cape Town and Berlin), for theoretical investigations in topics connected with quantum mechanies; Dr. O. B. Westcott (University College, Exeter), for rescarch on the electro-deposition of tin with the view of establishing the precise conditions under which crystalline deposits may be obtained and avoiding the unsatisfactory spongy deposits which result from present processes. In addition, the fellowships awarded a year ago to Mr. W. H. Wheeler, for research in chemical technology, and Mr. J. I. Armstrong, for plant physiology research, have been extended for a second year.

\section{Cancer Research}

The ninth annual report of the British Empire Cancer Campaign, presented at the annual meeting on July 11, illustrates the diversity of ways in which the cancer problem is being approached-observational, experimental, and clinical. The best discovery announced is the identification by the Cancer Hospital Research Institute of a pure chemical substance1:2:5:6-dibenzanthracene-which causes epithelial and connective tissue tumours in the great majority of treated animals. Some progress has also been made in perfecting an antiserum which will cure mouse tumours, but it remains questionable whether there is much prospect of applying the method successfully to human cases. The account of cancer as a gene mutation lacks something in historical perspective: it does no more than translate Boveri's hypothesis into modern terminology.

\section{Wool Production in the Empire}

The Wool Industries Research Association and the Empire Marketing Board are to be congratulated on their joint effort to make a survey of the conditions of wool production throughout the British Empire, particularly from the point of view of assessing the factors, economic and biological, which play a part in controlling production in different areas. The report, the result of a three years' survey by J. E. Nichols, has just appeared under the title " A Study of Empire Wool Production" (Wool Industries Research Association, Leeds; 5s. net). In 148 pages it would be impossible to follow all the vagaries of wool production, but Mr. Nichols has made the most of his space by discussing three main aspects : the conditions under which wool production occurs, and this includes geographical conditions as well as the conditions of the fleece itself ; the phases of wool production in the Empire, which means that the breeds of sheep, the qualities of the wools, the factors affecting the industry, are discussed for each country 
in turn; and finally, Part 3 "constitutes an attempt to analyse the concept of wool improvement and an examination of methods of development of its production".

\section{Academy of Natural Sciences of Philadelphia}

IN an attractive Year Book for 1931, it is recorded that the 120th year of the Academy's existence was signalised by notable activities in many directions. In each of the three major fields-laboratory studies, expeditions, and museum exhibits-the year set new records for this oldest institution of its kind in America. During the year, twenty-two expeditions for organised collecting, sponsored wholly or in part by the Academy, obtained material for study or exhibits from North, South, and Central America, as well as from Asia and Africa, and covered more than 175,000 miles during their quests. One result is seen in the addition of more than 8700 new specimens of vertebrates alone to the study collections. That the museum side of the Academy's activities arouses growing interest is indicated by the increased number of visitors, which for the first time exceeded 100,000; but the photographs of the cases of small mammals in the North American hall give an impression of the grouping of incongruous species, which suggests that here there is still room for the development of artistic natural groups. It is announced in Science that the following have recently been elected correspondents of the Academy : Prof. L. H. Bailey, Dr. H. B. Bigelow, Prof. R. A. Daly, Dr. Ludwig Diels, Prof. J. Stanley Gardiner, Prof. Hugo Glück, Prof. W. D. Gregory, Prof. A. S. Hitchcock, A. Lutz, Prof. E. de Margerie, Prof. E. D. Merrill, E. W. Nelson, Prof. A. C. Seward, Dr. E. O. Ulrich, and Mr. B. P. Uvarov.

\section{Eradication of Slugs and Snails}

SluGs and snails are some of the most widespread pests on farms and in gardens, but owing to their nocturnal habits and their capacity for excreting slime which enables them to get rid of irritating substances, they are very difficult to control. Their natural enemies, for example, various birds, toads, moles, and predaceous ground beetles, are insufficient to keep their numbers in check, and special means of control are often necessary. Though no means of absolute eradication of these pests is as yet known, the Ministry of Agriculture has published an Advisory Leaflet (No. 115), in which various check measures are described. In gardens, large numbers of slugs may be caught by means of traps consisting of cut potatoes, orange skins, cabbage leaves, tiles, boards, or sacking placed on the soil, for the animals will collect under them far shelter during the day. Hand collecting at dusk is also recommended. For larger areas, the use of certain chemicals with a corrosive or toxic action is advised. Quicklime or salt are destructive if they come in contact with the upper part of the slugs' bodies, and applications made at night (or two or three times during the same night, if possible) should prove useful. Barriers of repellent material such as soot, washing soda, 'dry Bordeaux ', etc., are often successful, and recent trials have shown that 1 part creosote mixed with 100 parts of precipitated chalk placed around each plant at the rate of $\frac{1}{4} \mathrm{oz}$. per plant is worth further trial.

\section{Forest Fires}

Leaflet No. 9 issued by the Forestry Commission (H.M.S.O., 1931) deals with this subject, which is of growing importance in Great Britain. The type of forests most subject is the coniferous ; outside tropical regions, fires in forests of broad-leaved trees are less dangerous. Woodland fires are not new in Great Britain, and in dry seasons they have been only too prevalent on commons. The Forestry Commission attributes twenty-five per cent of the fires occurring nowadays in its new forests to carelessness on the part of picnickers and wayfarers. Since the advent of the Forestry Commission and the large coniferous planting campaign which has been inaugurated under its auspices during the past twelve years, the forest fire problem has entered upon a new phase. The most common form of danger is the surface or ground fire, burning dead leaves, etc., on the forest floor. The stem and crown fire is rarer in Great Britain. Newly planted areas are in greatest danger during March and April, although a dry February produces the same conditions. During a summer drought the danger reappears. The grass, under the influence of dry east winds or a summer drought, becomes as dry as tinder, and a cast-away lighted match or burning cigarette-end will start a fire which will quickly get out of control of the perpetrator of the act. After pointing out the various dangers to plantations situated under differing conditions, the leaflet deals with various methods of control, such as lay-out of plantations, order of felling, removal of debris, patrolling, equipment of tool depots, clearance of growth outside plantations, importance of immediate action, counterfiring, and the measures to be taken after the outbreak.

\section{The Making of Factories}

IN Helios for March 20, the export journal of the Zeitschrift für die Elektrotechnik, there is an interesting account of the Gladitz Company of Berlin, the main business of which is to instal and equip completely in every detail lamp-making factories. Any one willing to start a factory for electric lamps need have no technical knowledge of the subject. For example, a capitalist in Mexico City recently ordered a modern lamp-making factory. The plans for the building were prepared by the company and it was erected under the supervision of a local architect. During this time the necessary equipment, down to the smallest detail, was made in Germany. German engineers then went to Mexico and installed the machinery. They took with them a staff of male and female workers. The Mexican labourers, both men and women, were instructed by this staff. In a year's time the instructors had all left, the only German remaining being the technical manager. Three months after the building was erected, lamps began to be manufactured, and the production is now 16,000 per day. The contract comprises the supply of all machines and accessories, the factory organisa-

No. 3272, VoL. 130] 